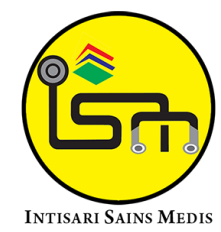

Published by Intisari Sains Medis

\title{
Case report of acute epiglottitis in a 44-year-old man: a rare case
}

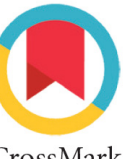

\author{
I Gusti Ayu Putu Wahyu Widiantari ${ }^{1 *}$, Nyoman Dian Permatasari ${ }^{1}$, \\ Ida Bagus Semara Putra ${ }^{1}$
}

${ }^{1}$ Otorhinolaryngology-Head and Neck Surgery Department Mangusada General Hospital, Badung, Bali

\section{*Corresponding to:}

I Gusti Ayu Putu Wahyu Widiantari;

Otorhinolaryngology-Head and Neck Surgery

Department Mangusada General Hospital, Badung,

Bali;

gekwahyu@gmail.com

Received: 2021-02-08

Accepted: 2021-09-15

Published: 2021-10-26

\section{ABSTRACT}

Background: Acute epiglottitis, also known as supraglottitis or supraglottic laryngitis, is an acute inflammation of the supraglottic area of the larynx. The diagnosis can be made based on clinical signs and symptoms as well as several investigations.

Case Description: We reported a case of a 44-yearold man who presented to our emergency department and whose condition was ultimately diagnosed as epiglottitis. Indirect laryngoscopy and lateral soft tissue neck radiograph had an important role in determining the diagnosis. The patient was treated conservatively by giving a high dosed antibiotic, anti-inflammatory, and analgesic drugs.

Conclusion: Acute epiglottitis can be a life-threatening condition because it can cause sudden upper airway obstruction. Therefore, management must be given quickly and precisely so as not to fall into a lifethreatening condition.
Keywords: epiglottitis, inflammation, odynophagia.

Cite This Article: Widiantari, I.G.A.P.W., Permatasari, N.D., Putra, I.B.S. 2021. Case report of acute epiglottitis in a 44-year-old man: a rare case. Intisari Sains Medis 12(3): 785-788. D0I: 10.15562/ism.v12i3.954

\section{INTRODUCTION}

Acuteepiglottitis, alsoknownassupraglottis or supraglottic laryngitis, is a state of acute inflammation of the supraglottic larynx area, including inflammation epiglottis, vallecula, arytenoid, and aryepiglottic folds. ${ }^{1}$ In 1900, Theisen first reported cases of acute epiglottitis as "anginapeptiloides". Since then, acute epiglottitis has been widely published in the pediatric literature. ${ }^{2}$ Epiglottitis is usually caused by a bacterial infection in the area, with the most common bacteria is Haemophilus influenzae type B. ${ }^{1,3}$ Epiglottitis commonly affects children aged $2-4$ years. Still, recently it has been reported that its prevalence and incidence are increasing in adults. ${ }^{2,4}$

The onset of acute epiglottitis symptoms is usually sudden and progresses rapidly. In pediatric patients, the most common symptoms are shortness of breath and stridor preceded by fever. In contrast, in adult patients, the symptoms are milder, and the most general complaints are sore throat and pain when swallowing. The diagnosis of epiglottitis can be made based on the history of the disease course, clinical signs, and symptoms. From a lateral X-ray of the neck showing epiglottic edema (thumb sign appearance) and the hypopharynx dilatation. ${ }^{3,5-7}$ The main goals of treatment in patients with acute epiglottitis are to keep the airways open and treat the underlying infection or other causes. ${ }^{4}$ Acute epiglottitis can be a life-threatening condition because it can cause sudden upper airway obstruction. Therefore, doctors must be aware of the possibility of epiglottitis in patients. Determining the diagnosis and providing precise management are the key role so that it does not become a life-threatening condition. $^{2,8-10}$

This case report aimed to discuss acute epiglottitis in 44-year-old male patients, which is a rare case, including diagnosis and management.

\section{CASE REPORT}

A 44-year-old male came to the Emergency Department (ED) Mangusada Hospital with difficulty swallowing one day before hospitalized. The patient complained of painful swallowing one day before hospitalized. The patient also has got a fever, chills, and profuse salivation. The patient had complained of coughs, colds, and fever one week before hospitalized. The patient then went to the Puskesmas and was given antibiotics, anti-inflammatory drugs, and cold medicine. However, the patient's complaints did not change, and symptoms like difficulty swallowing and painful swallowing have appeared after five treatment days. The patient also complains of a hoarse voice, swelling of the neck, and decreased appetite. The patient does not complain about shortness of breath.

The patient did not have a family with similar complaints. History of diseases such as high blood pressure, diabetes, or malignancy was denied. The patient admitted that he was an active smoker for more than 30 years, the type of filter cigarette, 1-2 packs/day. The patient does not drink alcohol. The patient admitted that he did not have a history of allergies to food, drugs, or other things. The patient has never received immunization against Haemophilus influenza type B. 
On his arrival to the ED, he was febrile to $38.5^{\circ} \mathrm{C}$, with a pulse of 82 , blood pressure of $110 / 70$, respiratory rate of 21 , and oxygen saturation of $98 \%$ on room air. He appeared nontoxic and was coloring while sitting upright. He had a muffled voice with mild stridor at rest. His head was tilted to the left, and he was exhibiting mouth breathing and spitting of his saliva. His neck examination showed bilateral cervical lymphadenopathy. He did not have any retractions and had good air entry bilaterally with no rales, wheezes, or rhonchi. Indirect laryngoscopy revealed diffuse edema and swelling of the epiglottis and aryepiglottic folds.

Complete blood count examination depicted severe leukocytosis (leukocyte count $28,96 \times 10^{3} / \mu \mathrm{l}$ ) with neutrophil level $84 \%$. Blood urea nitrogen, creatinine serum, and blood sugar level were still within normal limits. We also performed a SARS COV-2 serology examination, with the result of non-reactive SARS-COV2 IgG and IgM. A lateral soft tissue neck radiograph revealed an enlargement of the aryepiglottic folds and epiglottis (Figure 1).

He was given treatment, including intravenous fluid drops, a highdosed antibiotic (ceftriaxone), antiinflammatory (dexamethasone). On day 6 of hospitalization, we performed a lateral soft tissue neck radiograph to re-assess the epiglottis condition. As the symptoms were improved, the lateral soft tissue neck radiograph also revealed a normal size of the epiglottis, and there was no enlargement (Figure 2).

He was later discharged and given the oral treatment antibiotic (ciprofloxacin, $500 \mathrm{mg}$ twice daily), oral antiinflammatory (methylprednisolone, $8 \mathrm{mg}$ twice daily), and analgetic (paracetamol, $500 \mathrm{mg}$ ).

\section{DISCUSSION}

Abnormalities in the epiglottis and other supraglottic structures can cause airway obstruction, especially in severe conditions. The population at risk for epiglottitis is middle-aged men, have a history of smoking and individuals who have comorbid medical conditions such as diabetes. ${ }^{11-13}$ However, several patients do not have specific risk factors. ${ }^{12,14}$ A retrospective review also demonstrates that infants, those younger than one year of age, and those older than 85 years are

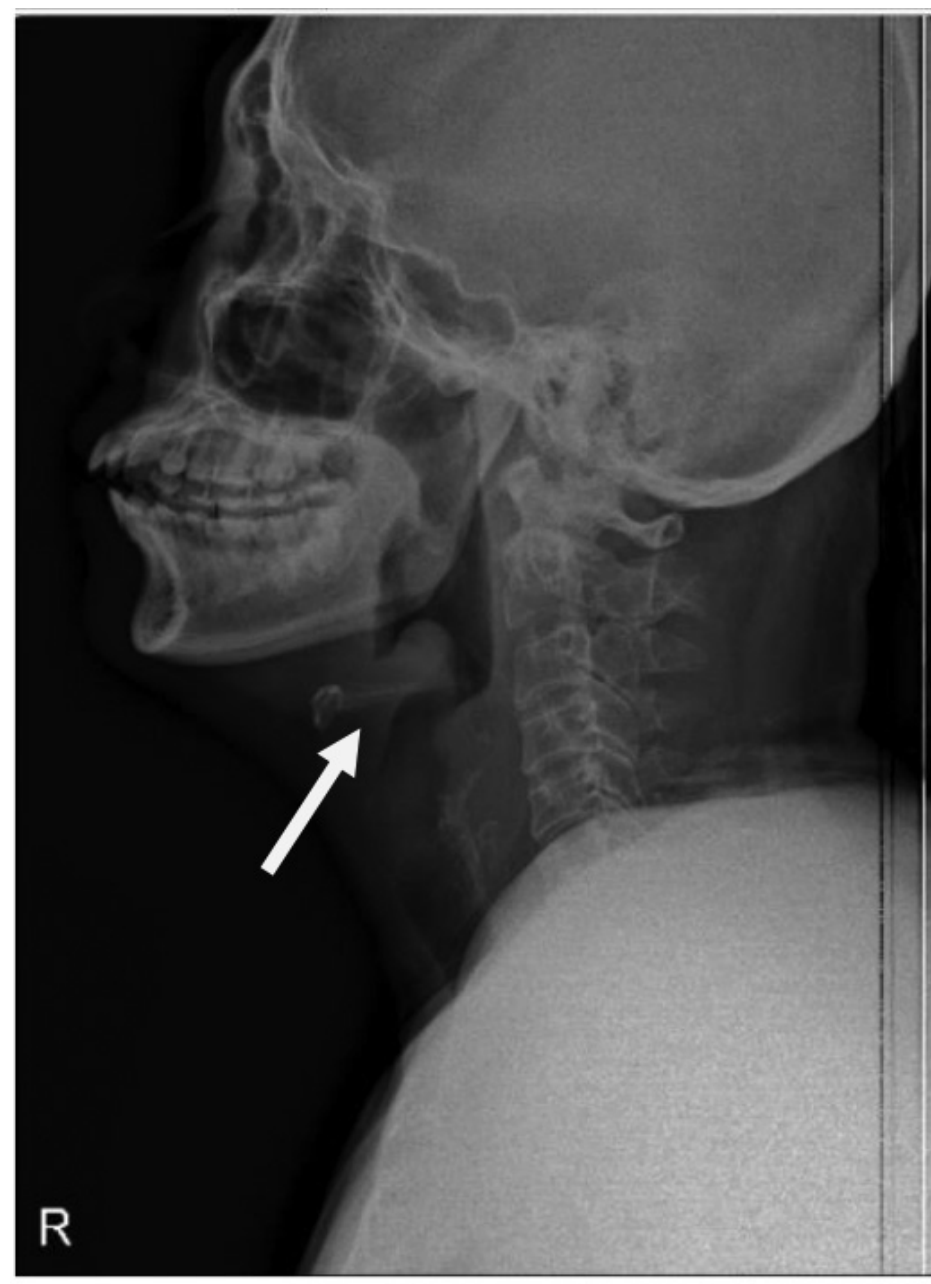

Figure 1. Lateral soft tissue neck radiograph revealed an enlargement of the epiglottis and aryepiglottic folds (single arrow), illustrating the classic thumb sign appearance.

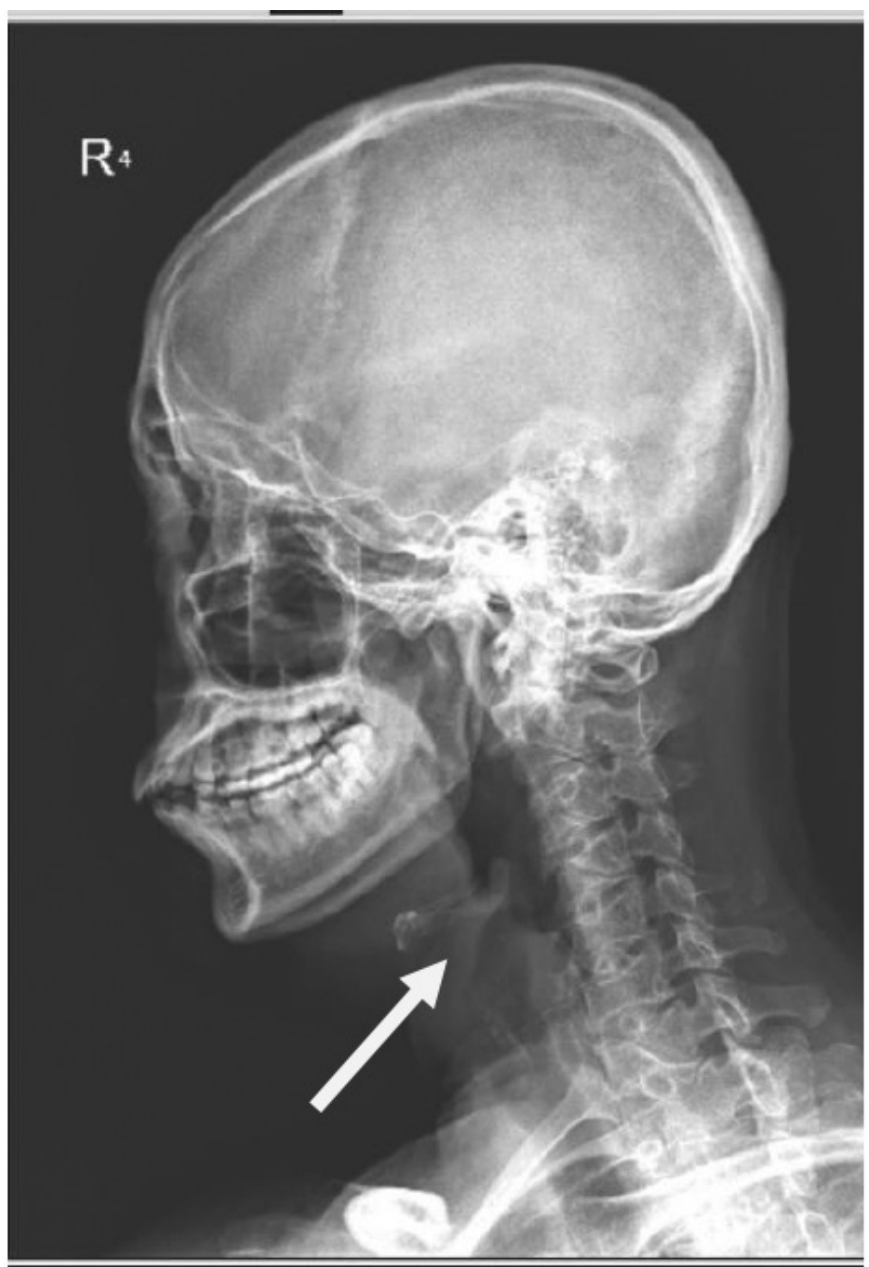

Figure 2. Lateral soft tissue neck radiograph on day 6 of hospitalization depicted epiglottis normal size (single arrow). 
particularly susceptible to this disease. ${ }^{14}$ In the United States, the incidence of adult epiglottitis increases at 45 to 64 years of age and in those older than 85 . That the diagnosis of acute epiglottitis is approximately 0.6 to 3 cases per 100,000 adult patients each year. ${ }^{14,15}$

Stridor and respiratory distress are considered strong predictors for airway intervention. ${ }^{12}$ However, less severe signs and symptoms, such as shortness of breath (which are subjective), tachycardia, tachypnea, and rapid onset of symptoms (less than 24 hours), have also been shown predictor of airway intervention. ${ }^{12}$ The mean length of hospital stay was four days. ${ }^{14,15}$ The clinical manifestations of epiglottitis are varied. Patients generally present with a sore throat, odynophagia, and voice changes. ${ }^{14,16}$ The clinical diagnosis is confirmed by nasopharyngoscopy with direct visualization of the inflamed epiglottis and supraglottic tissue. ${ }^{17}$ In stable patients, the emergency department may decide to perform a nasopharyngoscopy. However, a team approach in the operating room with the Anesthesiology and Otolaryngology Department is preferred to better visualize the epiglottis with clinical attention to possible airway obstruction. Lateral soft tissue neck radiograph may show the classic "thumb sign". ${ }^{17}$ Ultrasound and CT at the bedside may also be performed as additional investigations. ${ }^{18}$ Imaging modalities should be chosen based on caution and clinical considerations for alternative diagnoses. For example, CT imaging can be used in stable patients with conditions such as a retropharyngeal abscess. Additional investigations should not delay airway intervention in patients with respiratory distress. ${ }^{11}$

The etiology of epiglottitis includes both infectious and non-infectious entities. ${ }^{19}$ Infectious organisms such as bacteria, viruses, or fungi. ${ }^{19}$ The causative pathogens include Haemophilus influenza, Streptococcus pyogenes, Streptococcus pneumoniae, and Staphylococcus aureus. ${ }^{19-21}$ Antibiotics are the main therapy with steroids as a potential adjunctive therapy. ${ }^{14}$ Antimicrobial therapy should be adapted to suit the most common etiology and resistance patterns, with third-generation cephalosporins often recommended as monotherapy. ${ }^{19}$ Vancomycin should be given if methicillinresistant S. aureus (MRSA) is considered a cause of epiglottitis. The use of steroids is controversial, but some studies suggest that steroids contribute to hospital and ICU stay duration. ${ }^{12}$ Bronchodilators, such as epinephrine, are not effective in acute epiglottitis but may be considered in patients with airway obstruction while preparing for the intervention of breath control. ${ }^{22,23}$ Epinephrine should not be used in children because it can cause agitation and trigger a laryngeal spasm. ${ }^{24}$ Caution should also be used in elderly patients or patients with a history of myocardial ischemia or arrhythmia.

Treatment prioritized airway management. One retrospective review in 2010 revealed that $13.2 \%$ of patients diagnosed with epiglottitis required intubation, whereas $3.6 \%$ required tracheostomy. ${ }^{14}$ Supportive care and airway observation in the ICU are sufficient as management for most patients with epiglottitis. Careful planning to secure the airway is paramount as decompensated patients may require immediate intervention. ${ }^{12}$ Airway management should involve preparation for airway surgery with landmark identification and skin cleansing. The patient should be maintained in an upright position because the supine position can exacerbate airway obstruction. ${ }^{25,26}$

Visualization of the vocal cords should be obtained in a controlled setting, using intubation to allow spontaneous ventilation. ${ }^{27}$ Paralysis can exacerbate obstruction. Fiberoptic or video laryngoscopy should be considered. ${ }^{12,26-28}$ Clinicians should quickly recognize the failure of supraglottic intubation and perform a rapid cricothyrotomy. ${ }^{12}$ The importance of timely diagnosis and intervention of epiglottitis to prevent severe morbidity and death. Epiglottitis is a true airway emergency. Doctors must be aware of this condition because the symptoms that appear can vary.

\section{CONCLUSION}

Acute epiglottitis is an acute inflammatory state in the supraglottic region of the larynx. Epiglottitis can be caused due to a bacterial infection with the most common cause of bacteria, namely Haemophilus influenza type B. The onset of acute epiglottitis symptoms is usually sudden and progresses rapidly. In pediatric patients, the most common symptoms are shortness of breath and stridor preceded by fever. In contrast, in adult patients, the symptoms are milder. The most common complaints are sore throat and pain when swallowing. The diagnosis can be made based on clinical signs and symptoms as well as several investigations. Acute epiglottitis can be a life-threatening condition because it can cause sudden upper airway obstruction. Therefore, management must be given quickly and precisely so as not to fall into a life-threatening condition.

\section{CONFLICT OF INTEREST}

There is no conflict of interest in this case report.

\section{ACKNOWLEDGEMENT}

None.

\section{FUNDING SOURCES}

None.

\section{AUTHOR CONTRIBUTION}

The authors are equally contributed to the study's funding since the conceptual framework until reporting the results.

\section{REFERENCES}

1. Gompf, S.G. Epiglotitis 2011. Available from: http//emedicine.medscape.com.article/763612 (Accessed in November,13th 2020)

2. Chung, C.H. Case and Literature Review: Adult Acute Epiglottitis - Rising Incidence or Increasing Awareness. Hong Kong JEmerg Med.. Available from http://www.hkcem.com/ html/publications/Journal/2001-3/227-231.pdf [Accessed in November,13th 2020].

3. 3 Snow, J.B., Ballenger, J.J. Ballenger's Otorhinolaryngology Head and Neck Surgery. 16th Ed. USA: BC Decker; 2003:10901093,1195-1199.

4. Tolan, R.W. Pediatric Epiglottitis. 2011.Available from: http://http://emedicine.medscape.com/ article/963773 [Accessed in November,13th 2020].

5. Adams GL, Boies LR, Higler PA. Laring. In: Boies Buku Ajar Penyakit THT. Edisi 6. Cetakan Ketiga. Jakarta: EGC; 1997. P369-396

6. Probft R, Grevers G. Infectious Diseases of the Larynx and Trachea in Children. In :Basic 
Otorhinolaryngology.Stutgard, New York. Thieme. P354-356.

7. Dhingra, P.L. Acute and Chronic Inflammation of Larynx. In: Dhingra, P.L. Diseases of Ear, Nose and Throat. 4th Ed. USA: Elsevier; 2007

8. Chung, C.H. Acute Epiglottitis Presenting as the Sensation of a Foreign Body in the Throat. Hong Kong Med J. September 2000. Available from: http://www.hkmj.org/articledfs/hkm0009p322. pdf [Accessed in November,13th 2020].

9. Wick, F., Ballmer, P.E., Haller, A. Acute Epiglottitis in Adults. Swiss Med Wkly. 2002; 132: 541-546. Available from http://www.smw. $\mathrm{ch} / \mathrm{docs} / \mathrm{pdO} 00 \mathrm{v} 2002 / 37 / \mathrm{smw}-10050 . \mathrm{PDF}$ [Accessed in November,13th 2020].

10. Cummings, C.W. et al. Cummings Otolaryngology - Head \& Neck Surgery. 4th Ed. USA: Elsevier; 2010: 2065-2075.

11. Suzuki S, Yasunaga H, Matsui H, Fushimi K, Yamasoba T. Factors associated with severe epiglottitis in adults: analysis of a Japanese inpatient database. Laryngoscope 2015 Sep;125(9):2072-8. Available from: https:// doi.org/10.1002/lary.25114 [Accessed in November,13th 2020].

12. Guardiani E, Bliss M, Harley E. Supraglottitis in the era following widespread immunization against Haemophilus influenzae type B: evolving principles in diagnosis and management. Laryngoscope $2010 \quad$ Nov;120(11):2183-8. Available from: https://doi.org/10.1002/ lary.21083 [Accessed in November,13th 2020].

13. Chroboczek T, Cour M, Hernu R, et al. Longterm outcome of critically ill adult patients with acute epiglottitis. PLoS One 2015 May 6;10(5):e0125736. Available from: https://doi. org/10.1371/journal.pone.0125736 [Accessed in November,13th 2020].

14. Shah RK, Stocks C. Epiglottitis in the United States: national trends, variances, prognosis, and management. Laryngoscope 2010 Jun;120(6):1256- 62. Available from: https:// doi.org/10.1002/lary.20921 [Accessed in November,13th 2020].

15. Berger G, Landau T, Berger S, Finkelstein Y, Bernheim J, Ophir D. The rising incidence of adult acute epiglottitis and epiglottic abscess. Am J Otolaryngol 2003 Nov-Dec;24(6):374-83. Available from: https:// doi.org/10.1016/s01960709(03)00083-8 [Accessed in November,13th 2020].

16. Frantz TD, Rasgon BM, Quesenberry CP Jr. Acute epiglottitis in adults. Analysis of 129 cases. JAMA 1994 Nov 2;272(17):135860. Available from: https://doi.org/ 10.1001/ jama.1994.03520170068038 [Accessed in November,13th 2020].

17. Westerhuis B, Bietz MG, Lindemann J. Acute epiglottitis in adults: an under-recognized and lifethreatening condition. S D Med 2013 Aug;66(8): 309-11, 313.

18. Hung TY, Li S, Chen PS, et al. Bedside ultrasonography as a safe and effective tool to diagnose acute epiglottitis. Am J Emerg Med 2011 Mar;29(3):359.e1-3. Available from: https://doi.org/10.1016/j.ajem.2010.05.001 [Accessed in November,13th 2020].

19. Glynn F, Fenton JE. Diagnosis and management of supraglottitis (epiglottitis). Curr Infect Dis Rep 2008 May;10(3):200-4. Available from: https://doi.org/10.1007/s11908-008-0033-8 [Accessed in November,13th 2020].

20. Harris C, Sharkey L, Koshy G, Simler N, Karas JA. A rare case of acute epiglottitis due to Staphylococcus aureus in an adult. Infect Dis Rep 2012 Jan;4(1):e3. Available from: https:// doi.org/10.4081/idr.2012.e3 [Accessed in November,13th 2020].

21. Isakson $\mathrm{M}$, Hugosson S. Acute epiglottitis: epidemiology and Streptococcus pneumoniae serotype distribution in adults. J Laryngol Otol 2011 Apr;125(4):390-3. Available from: https:// doi.org/10.1017/s0022215110002446 [Accessed in November,13th 2020].
22. Ward MA. Emergency department management of acute respiratory infections. Semin Respir Infect 2002 Mar;17(1):65-71. Available from: https://doi.org/10.1053/srin.2002.31692 [Accessed in November,13th 2020].

23. Sobol SE, Zapata S. Epiglottitis and croup. Otolaryngol Clin North Am 2008 Jun;41(3):55166, ix. Available from: https://doi.org/10.1016/j. otc.2008.01.012 [Accessed in November,13th 2020].

24. Mandal A, Kabra SK, Lodha R. Upper airway obstruction in children. Indian J Pediatr 2015 Aug;82(8):737-44. Available from: https://doi. org/10.1007/s12098-015-1811-6 [Accessed in November,13th 2020].

25. Wiebe K, Rowe BH. Nebulized racemic epinephrine used in the treatment of severe asthmatic exacerbation: a case report and literature review. CJEM 2007 Jul;9(4):3048. Available from: https://doi.org/10.1017/ s1481803500015220 [Accessed in November,13th 2020].

26. Vermelis AM, Mateijsen $\mathrm{N}$, Giebelen $\mathrm{D}$, Meeusen V, Wong DT, van Zundert AA. Successful use of videolaryngoscopy in an adult patient with acute epiglottitis: a case report. Acta Anaesthesiol Belg 2010;61(2):67-70.

27. Riffat F, Jefferson N, Bari N, McGuinness J. Acute supraglottitis in adults. Ann Otol Rhinol Laryngol 2011 May;120(5):2969. Available from: https://doi.org/ $10.1177 / 000348941112000503$ [Accessed in November,13th 2020].

28. Garmel GM. Image diagnosis: abnormal plain films from the emergency department. Perm J 2009 Summer;13(3):47. Available from: https:// doi.org/10.7812/TPP/09-071 [Accessed in November, $\left.13^{\text {th }} 2020\right]$.

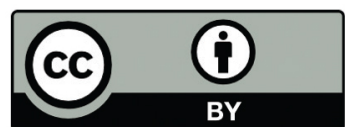

This work is licensed under a Creative Commons Attribution 